\title{
Oral supplementation of organic trace minerals to double-muscled Belgian Blue dams in late gestation: clinical and biochemical aspects
}

\author{
Klinische en biochemische aspecten van orale supplementatie van organische \\ sporenelementen aan Belgisch witblauwe koeien tijdens de late dracht
}

\author{
${ }^{1}$ H. Guyot, ${ }^{2}$ J. Martín-Tereso, ${ }^{3}$ W. Litjens, ${ }^{3}$ B. Brutsaert, ${ }^{4}$ L. Desmet, ${ }^{1}$ G. Cheleux, \\ ${ }^{1}$ P. Dubreucq, ${ }^{1}$ F. Rollin \\ ${ }^{1}$ Department of Sustainable Animal Production; Fundamental and Applied Research for Animals and Health, \\ University of Liège, Liège, Belgium \\ ${ }^{2}$ Trouw Nutrition Research \& Development, PO Box 220, 5830 AE Boxmeer, the Netherlands \\ ${ }^{3}$ Selko Feed Additives, PO Box 4217, 5004 JE Tilburg, the Netherlands \\ ${ }^{4}$ Trouw Nutrition Belgium, 4 Akkerhage, 9000 Ghent, Belgium
}

hugues.guyot@uliege.be

\begin{abstract}
A
BSTRACT

Beef cattle are susceptible to trace element deficiencies. The goal of this trial was to study the efficacy of dam supplementation with organic or inorganic trace minerals. Thirteen Belgian Blue farms divided into two groups per farm were investigated, resulting in a randomized block design, with two treatments. Animals in treatment A group received a supplement containing $50 \%$ organic and $50 \%$ inorganic selenium, zinc, and copper, while those in treatment $B$ group received $100 \%$ inorganic sources. Blood zinc $(p=0.08)$, selenium in blood $(p<0.01)$ and colostrum $(p<0.01)$ were higher in group A. No difference $(p>0.1)$ was found between treatments regarding the incidence of disease or daily weight gain of the calves. Although the zootechnical performance was equal for both treatments, supplementation with organic trace minerals resulted in a greater nutritional efficacy to sustain the selenium and zinc statuses of the Belgian Blue cattle, and also seemed to mitigate inflammation associated with cesarean section.
\end{abstract}

\section{SAMENVATTING}

Vleesvee is gevoelig voor een tekort aan sporenelementen. In deze studie wordt het effect van supplementatie met organische of anorganische sporenelementen onderzocht. Drachtige koeien op dertien Waalse bedrijven met Belgische witblauwe dieren werden verdeeld in twee gelijke groepen, resulterend in een "random-block-design" met twee behandelingen en zesentwintig experimentele eenheden (halve bedrijven) met het bedrijf als "block". De dieren in groep A kregen een supplement dat $50 \%$ organisch selenium, zink en koper bevatte en 50\% anorganische sporenelementen, terwijl de dieren in groep B $100 \%$ anorganische sporenelementen kregen. Zink in bloed $(\mathrm{p}=008)$, selenium in bloed $(p<0,01)$ en colostrum $(p<0,01)$ waren hoger in groep A. Er waren geen verschillen $(p>0,1)$ op het gebied van gezondheid en kalvergroei. Alhoewel de dierprestaties gelijk waren voor de twee verschillende behandelingen, resulteerde de supplementatie met organische sporenelementen in een hogere nutritionele efficiëntie voor het behoud van de selenium- en zinkstatus. Daarnaast leek deze supplementatie de ontsteking die geassocieerd is met een keizersnede te verminderen.

\section{INTRODUCTION}

Selenium $(\mathrm{Se})$, copper $(\mathrm{Cu})$, zinc $(\mathrm{Zn})$ and iodine (I) deficiencies are widespread in cattle in Europe (Mee and Rogers, 1994; Enjalbert et al., 2006; Guyot et al., 2009), with consequences for their health, production and reproduction (Graham, 1991). The hyper-muscled Belgian Blue (BB) breed is particularly prone to these deficiencies because of their exceptionally efficient feed conversion, which is associated with a low DMI $/ \mathrm{kg}$ of meat production dry matter intake resulting in higher dietary requirements per $\mathrm{kg}$ of feed (Ferret and Jenkins, 1998). Clinical signs are most common in calves, of which the trace mineral status is conditioned by that of their mothers and by the supply of these nutrients via placental transfer, co- 
Table 1. Mineral composition of the two supplements distributed to the dams.

\begin{tabular}{|c|c|c|c|}
\hline Component & Units & Group A & Group B \\
\hline Dry Matter & $\mathrm{g} / \mathrm{kg}$ & 958 & 959 \\
\hline $\mathrm{Ca}$ & $\mathrm{g} / \mathrm{kg}$ & 160 & 160 \\
\hline $\mathrm{P}$ & $\mathrm{g} / \mathrm{kg}$ & 60 & 60 \\
\hline $\mathrm{Mg}$ & $\mathrm{g} / \mathrm{kg}$ & 30 & 30 \\
\hline $\mathrm{Na}$ & $\mathrm{g} / \mathrm{kg}$ & 55 & 55 \\
\hline $\mathrm{Cl}$ & $\mathrm{g} / \mathrm{kg}$ & 84 & 92 \\
\hline $\mathrm{K}$ & $\mathrm{g} / \mathrm{kg}$ & 4 & 3 \\
\hline I (Potassium Iodide) (E2) & $\mathrm{mg} / \mathrm{kg}$ & 150 & 150 \\
\hline Co (Co-carbonate) (E3) & $\mathrm{mg} / \mathrm{kg}$ & 60 & 60 \\
\hline $\mathrm{Se}(\mathrm{Na}-$-selenite) (E8) & $\mathrm{mg} / \mathrm{kg}$ & 20 & 40 \\
\hline \multicolumn{4}{|l|}{ Se (Se enriched } \\
\hline \multicolumn{4}{|l|}{ Saccharomyces cerevisiae } \\
\hline NCYC R397 (Se-Met, Selko)) (3b8.11) & $\mathrm{mg} / \mathrm{kg}$ & 20 & / \\
\hline $\mathrm{Cu}(\mathrm{Cu}$ sulfate $)(\mathrm{E} 4)$ & $\mathrm{mg} / \mathrm{kg}$ & 700 & 1400 \\
\hline \multicolumn{4}{|l|}{$\mathrm{Cu}$ (chelate (E4) from OptiMin } \\
\hline $\mathrm{Cu} 15 \%$ (Selko)) & $\mathrm{mg} / \mathrm{kg}$ & 700 & / \\
\hline $\mathrm{Zn}(\mathrm{Zn}$ sulfate $)(\mathrm{E} 6)$ & $\mathrm{mg} / \mathrm{kg}$ & 2500 & 5000 \\
\hline \multicolumn{4}{|l|}{ Zn (chelate (E6) from OptiMin } \\
\hline Zn 15\% (Selko)) & $\mathrm{mg} / \mathrm{kg}$ & 2500 & l \\
\hline Vitamin A (E672) & $\mathrm{IU} / \mathrm{kg}$ & 1000000 & 1000000 \\
\hline Vitamin D3 (E671) & $\mathrm{IU} / \mathrm{kg}$ & 100000 & 100000 \\
\hline Vitamin E (3a700) & $\mathrm{IU} / \mathrm{kg}$ & 1000 & 1000 \\
\hline
\end{tabular}

lostrum and milk (Abdelrahman and Kincaid, 1993; Abdelrahman and Kincaid, 1995; Guyot et al., 2007; Guyot et al., 2011a). The numerous trace mineral supplements available in Europe are commonly classified as inorganic or organic minerals, separating simple salts and oxides from their complexes with organic ligands, as well as the selenite and selenate forms of Se from selenomethionine-based supplements. Selenomethionine, mostly produced by yeast culture enrichment, has proven to be more effective in transferring Se to colostrum and milk than Na-selenite (Guyot et al., 2007; Muniz-Naveiro et al., 2008). Se-methionine has been demonstrated to improve the health and performances of BB cattle (Guyot et al., 2007). Various studies have also demonstrated the value of $\mathrm{Zn}$ and $\mathrm{Cu}$ organic forms in improving the $\mathrm{Cu}$ and $\mathrm{Zn}$ statuses, although the benefits on health, reproduction and production remain controversial (Nockels et al., 1993; Malcolm-Callis et al., 2000; Schlegel et al., 2006). The majority of nutritional supplements are formulated from inorganic sources due to the additional cost of feeding beef dams with organic $\mathrm{Zn}, \mathrm{Cu}$ and Se sources.

The aim of this study was to assess the nutritional efficacy of a partially organic $\mathrm{Zn}, \mathrm{Cu}$ and Se feed supplement, compared to a fully inorganic mineral source, to supply trace elements to BB cows and indirectly to their calves.

\section{MATERIALS AND METHODS}

\section{Farms and Animals}

Thirteen commercial BB cattle farms were selected in Wallonia (the southern part of Belgium) during the winter of 2015. The following selection criteria were used to select farms: good management practices (including deworming programs against endoparasites and exoparasites, general hygiene and biosecurity, hoof health assessment and trimming at least once a year, a good body condition score of animals $(\mathrm{BCS} \geq 3.5)$, routine analysis of rations once a year), a minimum of twenty calvings during the winter period (November to March 2015), and the possibility of creating two separate feeding groups of cows and heifers in late gestation as well as supplying them with the same basic ration and two different mineral supplements during the entire study period. Only cows due to calve during the study period were selected (using rectal palpation and ultrasonography to determine the expected date of calving). A minimum of ten to a maximum of forty animals per group in each farm were involved. The experimental design was a split-plot design, in which farms were split in two groups, and treatments were applied at random to the two groups defined in each farm. This resulted in a randomized control design, with 26 halffarm experimental units (with 13 farms as the blocks) 
and two treatments, which were randomized at each farm and blindly applied by coding the products to the farmers and veterinarians. The pregnant cows in each farm were divided into two groups that were as similar as possible in terms of the gestation stage and parity of the included cows. The two treatments were then randomly assigned to each group $(A=$ organic; $\mathrm{B}=$ control). The age, parity and weight of the dams were homogeneously distributed between the groups. Initially, 830 healthy pregnant cows were selected for the study, 411 in group A and 419 in group B. Most cows were housed in stanchion barns. As is standard practice in the BB breed, all calves were delivered by caesarean section. Surgery was performed by the veterinarians of the farms, who also assisted in blood sampling at calving. The calves were weighed at birth to calculate their average daily gain (ADG) at the end of the study. The calves were either suckling- or bucket-fed (with whole milk or a milk-replacer). The amounts of whole milk and milk-replacer varied according to the farm, but globally represented $9-10 \%$ of the body weight in volume, with a maximum of 6-7 liters per day, given in 2-3 meals. A calf-starter (17\% crude protein) was distributed to the calves after the first week of life. Water was available all the time. ADG, mortality and morbidity rates were calculated including all feeding systems, as well as only considering the most represented group of calves (suckling calves).

\section{Rations and mineral supplementation}

The ration of all pregnant dams was designed to meet all of the nutritional requirements in terms of energy, protein, dry matter, fibers and minerals according to the recommendations of the French Institute of Agricultural Research (INRA, 1988). The rations were formulated for each farm and considered to be equal at an expected feed intake of $10 \mathrm{~kg}$ of dry matter (DM). The basic ration for the animals was mainly composed of grass silage that was analyzed for each farm (BLGG AgroXpertus, Wageningen, the Netherlands), including trace minerals (iron (Fe), manganese (Mn), Zn, Cu, Se and I). Corn silage was also provided in seven farms and was analyzed in the same laboratory. When the roughage quality required additional supplementation to meet the nutritional requirements, the basal ration was supplemented with dried beet pulp or spelt/barley (less than $1 \mathrm{~kg}$, fresh). Following standard nutritional practices, the trace mineral contents of the forage material and supplements were not considered to tailor mineral supplements for each basal diet. Instead, a common mineral supplement formulation was used for all farms, with the aim of being adequate regarding the variability of the basal mineral contents of the forage rations of the selected farms.

Each pregnant dam received a daily mineral supplement (100 g/day) (Table 1). The dose was determined by volume with a measuring glass and top dressed on the ration by the herdsman for at least two months before calving (60-75 days). The mineral supplements consisted of $100 \%$ inorganic minerals (treatment B) or an equivalent mineral supplement, in which $50 \%$ of $\mathrm{Se}, \mathrm{Cu}$ and $\mathrm{Zn}$ had been replaced by OptiMin $\mathrm{SeY}$ (63\% seleno-methionine Se enriched yeast, NCYC R397), OptiMin Cu 15\% and OptiMin Zn 15\% (Selko Feed Additives, Nutreco) (treatment A). For an expected daily feed intake of $10 \mathrm{~kg}$ of DM, each pregnant cow (with an average body weight of $600 \mathrm{~kg}$, including heifers) should have received a daily supply until calving of $4 \mathrm{mg}$ of Se, $140 \mathrm{mg}$ of $\mathrm{Cu}, 500 \mathrm{mg}$ of $\mathrm{Zn}, 15 \mathrm{mg}$ of I, $6 \mathrm{mg}$ of Co, 100,000 IU of vitamin A, 10,000 IU of vitamin $\mathrm{D}_{3}$ and $100 \mathrm{IU}$ of vitamin $\mathrm{E}$. This formulation was chosen to meet the beef cattle requirements (according to NRC, 2000; Guyot et al., 2007). The mineral mixtures were formulated to have equal elemental mineral contents by the use of wheat

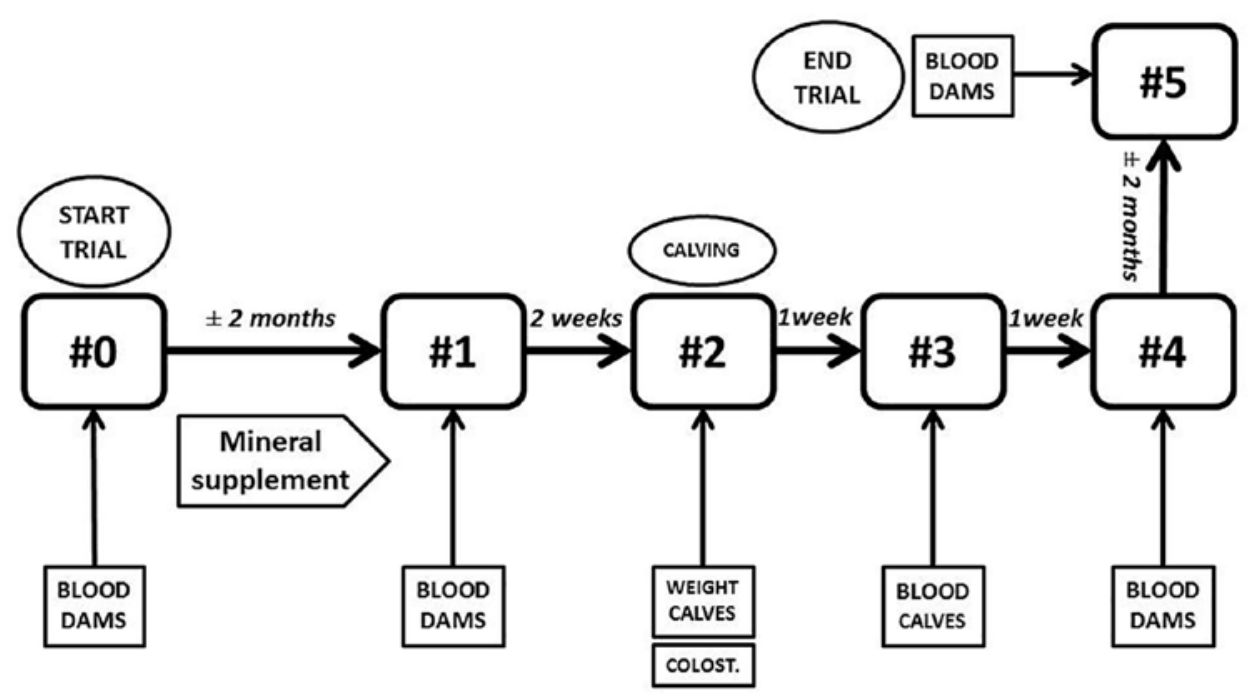

Figure 1. Time overview of the study protocol. 
bran as a carrier. Trace mineral supplementation of the dams was discontinued at calving.

After birth, the calves either suckled from their dams (six farms) or were bucket-fed using milkreplacer or whole milk (five and two farms, respectively). The calves were not supplemented with trace minerals, although calf milk-replacers contain mineral supplements. In all farms, 2.5 to $4 \mathrm{~L}$ of colostrum (fresh from the mother and/or frozen from a different dam of the same group) were bottle-fed within 18 hours after calving to the calf by the farmer. However, a large majority of calves received an adequate amount of colostrum (4 L).

\section{General protocol}

The trial was scheduled as summarized in Figure 1.

Fortnightly visits were organized to check for mineral consumption, collect clinical data from dams and calves as recorded by the farmer and veterinarian, take blood samples (cows and calves while needed), and correct protocol tracking. In each group, blood samples were taken from the same seven dams at $\# 0$ (beginning of the trial, before the first trace mineral supplementation), \#1 (45-60 days after \#0 and approximately two weeks before calving \#2), \#4 (approximately two weeks after calving \#2) and \#5 (end of the trial, approximately 45-60 days after \#4, or 6075 days after calving \#2). Colostrum was sampled in as many cows as possible. Blood was also sampled on every calf later than the second day of life but during the first week of life (\#3) to determine the passive transfer of colostral immunoglobulins, determined by measuring total proteins in serum (refractometer, see further). The plasmatic $\mathrm{Se}, \mathrm{Cu}, \mathrm{Zn}$, I and total proteins in the serum and plasma were assayed in the dams at $\# 0, \# 1, \# 4$ and $\# 5$, while thyroid hormones and haptoglobin (Hp) were only determined at $\# 0$ and \#4. The calves were investigated for thyroid hormones and serum total proteins 48 hours after birth (\#3). Colostrum was analyzed for the total protein, immunoglobulin $G$ (IgG) and Se contents. Sick animals and/or those with inflammation (elevated blood concentrations of $\mathrm{Hp}$ $>30 \mathrm{mg} / \mathrm{L}$ ) at $\# 0$ were excluded from the trial because inflammation may influence the trace mineral status (Milanino et al., 1986).

\section{Data collection and analyzes}

Clinical examination was performed at the beginning of the study to ensure the good health status of the tested animals. The examination was completed according to Rosenberger's 1990 guide for the complete clinical examination of bovines and included rectal and peripheral temperature measurements, lymph node and mucous membrane inspections, cardio-pulmonary investigation, digestive system auscultation, hydration status assessments and reproductive tract and udder palpations. During the study, health events (death, abortion, disease) were recorded, and sick ani- mals were systematically examined. The calves were weighed with a calibrated tension spring scale at birth and at 60-75 days of life (end of the trial) to calculate the ADG.

Blood was collected at different times of the protocol; in the dams from the coccygeal vein and in the calves from the jugular vein in Plain, EDTA and NaHeparin tubes (Figure 1). The samples were centrifuged ( 20 minutes, $1500 \mathrm{x} \mathrm{g}$ ) within three hours after the visit, and the plasma/serum samples were separated and frozen $\left(-22^{\circ} \mathrm{C}\right)$ prior to analysis. Plasmatic $\mathrm{Cu}, \mathrm{Zn}$ and $\mathrm{Se}$ were assayed by Inductivity Coupled Plasma/Mass Spectrophotometry (ICP-MS). Then, plasmatic inorganic iodine (PII) was analyzed using ion-exchange chromatography (Aumont and Tressol, 1987). In serum, thyroxin (T4) and tri-iodo-thyronine (T3) were tested using RIA, and Hp was measured using a hemoglobin (Hgb) binding capacity method (Owen et al., 1960) adapted to an automated analyzer (Olympus AU 510, Melville, NY, USA). The total protein (TP) of the serum/plasma was assessed using a digital refractometer (Euromex ${ }^{\circledR}$, Arnhem, the Netherlands). The serum Hp concentration was considered to be the main indicator of inflammation, and the difference of TP in the serum/plasma (fibrinogen estimation) was also used as a secondary indicator of inflammation in the dams (Guyot et al., 2011b).

Colostrum was collected at calving. The colostrum sample was thereafter frozen at $-22^{\circ} \mathrm{C}$ for further analysis. The Se content of the colostrum was measured by ICP-MS, and the IgG content of colostrum was assessed by radial immunodiffusion (RID).

The failure of passive transfer of immunoglobulins was assessed by measuring the total protein in the serum of the calves between two and seven days of life, which should be above $56 \mathrm{~g} / \mathrm{L}$ (Vandeputte et al., 2011).

\section{Statistical approach}

The study was organized as a prospective, randomized-controlled design carried out in 13 farms. The cows were divided in two groups as a split-plot design, in which each farm was considered to be a plot and each half farm was the experimental unit. Following the principles of the randomized block design, the treatments were randomly assigned within the blocks (farms) to the farm subgroups, which were considered to be 26 experimental units used in the statistical analyzes. The study was blinded to the farmers and veterinarians and to the experimenters during data processing and experimental analyzes.

Individual cow and calf observations were filtered for "outliers" (accidents in calves/dams [crushing, broken legs, $\mathrm{N}=11$ ] or accidental trace mineral administration/ingestion other than those provided by the protocol $\mathrm{N}=0$ ). The averages and counts of binomial and multinomial observations were calculated for each farm subgroup (experimental unit) to build the matrices that were used for statistical processing. 
Table 2. Zootechnical and health parameters in calves and their dams (mean and SD for dams and mean and standard error of the mean (SEM) for calves, if applicable) in groups A (organic mineral) and B (control). No significant differences were noticed between the treatment groups for the considered zootechnical and health parameters.

\begin{tabular}{lcc}
\hline Dams & Group A (n=411) & Group B (n=419) \\
\hline Parity (n calving) & $2 \pm 1$ & $14^{*}$ \\
Abortion* (n) & $2 \pm 1$ & $8^{*}$ \\
Not calving during study* (n) & $53^{*}$ & 26 \\
Sick cows (n) & 24 & $5^{*}$ \\
Dead cows* (n) & $4^{*}$ & Group B (n=333) \\
\hline Calves & Group A (n=344) & $52.6(1.2)$ \\
\hline Birth weight (kg) & $53.5(1.2)$ & $0.61(0.11)$ \\
ADG (kg) & $0.62(0.11)$ & $50 / 333(15.0 \%)$ \\
Sick calves (n) (morbidity rate) & $56 / 344(16.3 \%)$ & $24 / 333(7.2 \%)$ \\
Dead calves (n) (mortality rate) & $17 / 344(4.9 \%)$ & \\
\hline
\end{tabular}

*Animals removed from the protocol.

(n): number of animals

The averages of each farm subgroup for calf performance (ADG), calf serum and colostrum characteristics were studied as continuous variables with PROC MIXED of SAS (version 9.3) using the block (farm) as a random effect. Binomial events in the calving process of each farm subgroup (morbidity, mortality) were studied with PROC GENMOD of SAS (version 9.3) using the logit transformation.

Dam serum minerals and other serum continuous variables at $\# 0$ were compared between the treatments with PROC MIXED to check the validity of the blocking and randomization process. Repeated observations of the serum mineral, plasma and serum proteins and their differences were analyzed with PROC MIXED, with the farm as the random variable and the \#0 values as the covariables. The REPEATED statement was used, and TOEP (Toeplitz matrix) was assigned as a covariance structure. Hp, thyroid hormones, and their ratios were analyzed as non-repeated measurements. The other continuous variables were assessed using the $\# 0$ values as covariables. Serum minerals, haptoglobin and thyroid hormones farm subgroup clustering in three status levels were analyzed as multinomial cumulative parameters with GENMODE, using MULTINOMIAL and CUMLOGIT as options for the analyzes. A significance level of 5\% was used in the statistical interpretation.

\section{RESULTS}

The ration of the dams was quite similar regarding general composition and nutrients content at the selected farms despite differences in the roughage quality between farms. Nevertheless, the roughages were harvested in the southern part of Belgium, which is known to be a Se-deficient region. In most farms, grass silage was distributed, and in some farms, hay, maize silage or dried beet pulp was added. The basal diet (crude nutrients) was composed of $10 \mathrm{~kg}$ of DM $\pm 1 \mathrm{~kg}$ of $\mathrm{DM}$ (mean $\pm \mathrm{SD}$ ), with a global energy content of $7.2 \pm 0.7$ KVEM ("kilo voeder eenheid melk" or feed unit lactation), global protein content of 565 $\mathrm{g} \pm 49 \mathrm{~g}$ of CP (crude protein content), and $384 \mathrm{~g} \pm$ $37 \mathrm{~g}$ of DVE ("darm verteerbaar eiwit" or true protein digested in small intestine) (Dutch nutrients measurement units). The analysis of the total ration of the farms before mineral supplementation revealed an excess of $\mathrm{Fe}$ in 3/13 farms and an inadequate supply of $\mathrm{Se}$ in 8 farms, $\mathrm{Cu}$ in 7 farms, $\mathrm{Zn}$ in 7 farms and $\mathrm{I}$ in 4 farms. Four farms presented an inadequate supply of each of these four trace elements in the total ration.

\section{Zootechnical and health aspects}

The study started with 830 dams, of which 162 animals were removed, resulting in a total of 668 animals that completed the entire trial, with 340 in group A and 328 in group B. Cows were discarded from the analysis if they died or were sold before the end of the study $(\mathrm{n}=9$ ], had the wrong calving date and/or protocol schedule $(\mathrm{n}=[131])$, or suffered an abortion $(n=22])$. More calves than cows were included in the study because of the occurrence of twin calvings, representing a total of 677 calves: 344 in group A and 333 in group B.

The parity structure of the dams was similar between treatment groups, with approximately $1 / 3$ of primiparous cows in both groups. No significant difference was observed between groups $\mathrm{A}$ and $\mathrm{B}$ in terms of the incidence of abortions (A versus $B$, $p=0.19)$, sick cows (A versus $B p=0.71)$, dead cows (A versus $B p=0.76$ ), sick calves (A versus $B p=0.47$ ), dead calves (A versus $B p=0.36$ ) (excluding fatal accidents and congenital defects), and the ADG of calves (A versus $B \mathrm{p}=0.85$ ) (all feeding systems included). The mean weight of calves at birth was not different between the groups (A versus $B ; p=0.46$ ). The sex ra- 
tio of the calves was similar in both groups $(51 \%$ of males and $49 \%$ of females) and, in general, between the farms. No significant differences were observed between the treatment groups (including all calf feeding alternatives) for the zootechnical (birth weight, ADG) and health parameters considered (morbidity, mortality) (Table 2). Regarding only suckling calves' morbidity and mortality, there was also no significant difference between groups A and B, as well as comparing with all calves (all feeding alternatives). However, across treatments, the ADG was $795 \mathrm{~g}$ /day in suckling calves $(\mathrm{n}=494), 343 \mathrm{~g} /$ day in milk-replacer fed calves $(\mathrm{n}=108)$, and $543 \mathrm{~g} /$ day in milk fed calves $(\mathrm{n}=75)$

\section{Biochemical aspects}

\section{Basal condition at the start of the study: \#0}

No differences between treatment groups were found at $\# 0$ for $\mathrm{Zn}(\mathrm{p}=0.28), \mathrm{Cu}(\mathrm{p}=0.58)$, Se $(\mathrm{p}=0.40), \mathrm{I}(\mathrm{p}=0.21)$, thyroxin $(\mathrm{p}=0.43)$, tri-iodothyronine $(\mathrm{p}=0.57)$, total proteins in serum $(\mathrm{p}=0.49)$, total proteins in plasma $(\mathrm{p}=0.50)$ or haptoglobin $(\mathrm{p}=0.56)$ (Table 3). Regarding Se, $87 \%$ of all tested animals were considered to be deficient $(<65 \mu \mathrm{g} /), 11 \%$ marginal $65-80 \mu \mathrm{g} / \mathrm{L}$ ) and $2 \%$ adequate. Globally, the mean plasma Se concentration was below the threshold for the 13 farms in the study. For Zn, 53\% of the dams had adequate levels, while $47 \%$ had marginal levels $(8-14 \mu \mathrm{mol} / \mathrm{L})$. For only three farms, the mean plasma $\mathrm{Zn}$ concentration was below the threshold. For $\mathrm{Cu}, 82 \%$ of the dams had adequate levels, $17 \%$ had marginal levels $(8-13 \mu \mathrm{mol} / \mathrm{L})$ and $1 \%$ were deficient $(<8 \mu \mathrm{mol} / \mathrm{L})$. The mean plasma $\mathrm{Cu}$ concentration was above the threshold for all farms. For I, 36\% of the dams were deficient $(<15 \mu \mathrm{g} / \mathrm{L}), 36 \%$ marginal (15$45 \mu \mathrm{g} / \mathrm{L})$ and $28 \%$ adequate. Three farms had a mean plasma I concentration above the threshold. Finally, there was no inflammation ( $\mathrm{Hp} \leq 30 \mathrm{mg} / \mathrm{L})$ in $90 \%$ of the animals, while 5\% presented marginal inflammation and 5\% had true inflammation. The last cases came from one of the 13 farms that had a mean $\mathrm{Hp}$ concentration $(54 \mathrm{mg} / \mathrm{L})$ above the threshold, but the elevation was due to three clinical inflammation cases that were removed from the study, according to the exclusion criteria in the protocol.

\section{Study time points}

In Table 3, the mean concentrations of $\mathrm{Se}, \mathrm{Zn}, \mathrm{Cu}$, total protein, thyroid hormones and $\mathrm{Hp}$ are summarized in dams at $\# 0, \# 1, \# 4$ and $\# 5$, where the main differences between treatments were observed for Se (\#1, \#4, \#5,), haptoglobin (\#4) and Zn (\#4, only a tendency $\mathrm{p}=0.08$ ) in favor of treatment A.

After initiation of mineral supplementation, the Se status was higher in treatment $A(p<0.01)$ than in treatment $\mathrm{B}$ at all time points $(\# 1, \# 4, \# 5)$. At time points \#1-\#4-\#5, the Se status was also significantly higher than at $\# 0(p<0.01)$. At $\# 1$ and $\# 5$ and barely in $\# 4$, the Se status was above the recommended thresh-

Table 3. Mean (and standard error of the mean (SEM)) of Se $(\mu \mathrm{g} / \mathrm{L}), \mathrm{Zn}(\mu \mathrm{mol} / \mathrm{L}), \mathrm{Cu}(\mu \mathrm{mol} / \mathrm{L})$, thyroxin $(\mathrm{T} 4)(\mathrm{nmol} / \mathrm{L})$, tri-iodo-thyronine (T3) (nmol/L), total protein in serum (STP) (g/L) and plasma (PTP) (g/L) and haptoglobin (Hp) $(\mathrm{mg} / \mathrm{L})$ concentrations at \#0, \#1, \#4 and \#5 in the dams in the two treatment groups.

\begin{tabular}{|c|c|c|c|c|c|c|c|c|c|c|c|}
\hline Time & Group & $\mathrm{Zn}^{*}$ & $\mathrm{Cu}^{*}$ & $\mathrm{Se}^{*}$ & $I^{*}$ & STP & PTP & STP-PTP & T4* & T3* & Нр \\
\hline & Adequate & $14-21$ & $13-18$ & $80-140$ & $45-650$ & - & - & $* *$ & $30-120$ & $0.88-4.05$ & $* * *$ \\
\hline \multirow{3}{*}{$\# 0$} & A & 14.7 & 14.9 & 44.2 & 76.0 & 70 & 75 & 5 & 52 & 1.04 & 8 \\
\hline & B & 14.0 & 14.8 & 42.8 & 52.9 & 71 & 75 & 6 & 56 & 1.01 & 11 \\
\hline & SEM & 0.4 & 0.3 & 3.8 & 28.2 & 1 & 1 & 1 & 4 & 0.07 & 3 \\
\hline \multirow[t]{3}{*}{$\# 1$} & A & 14.6 & 13.2 & $85.6 \mathrm{~A}$ & - & 69 & 74 & $5 a$ & - & - & - \\
\hline & B & 15.0 & 12.7 & $76.0 \mathrm{~B}$ & - & 67 & 73 & $6 b$ & - & - & - \\
\hline & SEM & 0.6 & 0.5 & 2.6 & - & 1 & 1 & 1 & - & - & - \\
\hline \multirow[t]{3}{*}{$\# 4$} & A & 16.2 & 19.0 & $78.8 \mathrm{~A}$ & - & 78 & 83 & 4 & 53.0 & 0.99 & $123 a$ \\
\hline & B & 15.2 & 19.0 & $68.6 \mathrm{~B}$ & - & 77 & 81 & 4 & 59.3 & 1.03 & $301 b$ \\
\hline & SEM & 0.6 & 0.5 & 2.6 & - & 1 & 1 & 1 & 4.1 & 0.07 & 62 \\
\hline \multirow[t]{3}{*}{$\# 5$} & A & 14.3 & 15.8 & $85.6 \mathrm{~A}$ & - & 75 & 79 & 5 & - & - & - \\
\hline & B & 14.1 & 15.3 & $75.4 \mathrm{~B}$ & - & 75 & 80 & 5 & - & - & - \\
\hline & SEM & 0.6 & 0.5 & 2.6 & - & 1 & 1 & 1 & - & - & - \\
\hline
\end{tabular}

a,b: $(\mathrm{p}<0.05), \mathrm{A}, \mathrm{B}:(\mathrm{p}<0.01)$

*Adequate Zn, Cu, Se, I, T4, T3 status (Guyot and Rollin, 2007; Guyot et al., 2007; Guyot et al., 2009; Herdt et al., 2000).

**STP-PTP: the subtraction of serum TP to plasma TP (absolute value) estimating the fibrinogen concentration. Concentration should be $<6$ (Guyot et al., 2011b).

$* * *$ Absence of inflammation: at $\# 0 \leq 30$; at \#4 $<150$ (Humblet et al., 2006). 
old in treatment $\mathrm{A}$, but below the threshold for treatment B. $\mathrm{Zn}$ showed a trend $(\mathrm{p}=0.08)$ in favor of treatment $\mathrm{A}$ at \#4. There was no difference in the $\mathrm{Zn}$ status between $\# 0(p=0.58), \# 1(p=0.99)$ and $\# 5(p=091)$. A significant difference was seen at \#4 in the two treatments compared to $\# 0$ or $\# 5(\mathrm{p}<0.05)$. No difference was found between the treatments at any time point for $\mathrm{Cu}(\mathrm{p}>0.1)$ or for the total proteins in the serum/ plasma ( $p>0.1)$. The $\mathrm{Cu}$ statuses at $\# 0$ and $\# 5$ were not different ( $p>0.1)$; however, the $\mathrm{Cu}$ status at \#4 was higher for both treatments compared to \#0, \#1 and \#5 $(p<0.0001)$. The thyroid hormones and their ratios were also not different $(p>0.1)$ between the treatments and times ( $\# 0$ and $\# 4)$.

At $\# 1,69 \%$ of the animals had adequate Se levels in treatment $\mathrm{A}$ group, while only $35 \%$ had adequate Se levels in treatment B group. For Zn, $65 \%$ were adequate in treatment $\mathrm{A}$ and $63 \%$ in treatment $\mathrm{B}$. For $\mathrm{Cu}, 46 \%$ were adequate in treatment $\mathrm{A}$ and $40 \%$ in treatment B.

At \#4, $57 \%$ of the animals in treatment A were adequate for Se and $14 \%$ in treatment B. For $\mathrm{Zn}, 82 \%$ of the animals were adequate in treatment $\mathrm{A}$, while $61 \%$ were adequate in treatment $\mathrm{B}$. For $\mathrm{Cu}, 100 \%$ of the animals were adequate in both treatments.

At the end of the study (\#5), 67\% of the animals in treatment A were adequate for Se, while only $40 \%$ were adequate for Se in treatment B. For $\mathrm{Zn}$, both treatments were adequate for $56 \%$ of the animals. $\mathrm{Cu}$ was adequate in $85 \%$ of the animals in treatment $\mathrm{A}$ and $77 \%$ in treatment $\mathrm{B}$.

Regarding inflammation, the $\mathrm{Hp}$ concentration was lower at \#4 for treatment $\mathrm{A}(\mathrm{p}<0.05)$ compared to treatment $\mathrm{B}$, while the total protein in the serum and differences between STP and PTP were not significantly different between the treatment groups $(p>0.1)$.
In treatment group $\mathrm{A}$, the global $\mathrm{Hp}$ concentration did not exceed the threshold value $(150 \mathrm{mg} / \mathrm{L})$, whereas that of treatment B did.

The colostrum total protein $(\mathrm{p}=0.67)$ and $\mathrm{IgG}$ $(p=0.99)$ in the colostrum were not significantly different between the treatments, although the Se content in the colostrum was nearly double in treatment $\mathrm{A}$ $(p<0.01)$ compared with treatment B $(83 \%$ adequate in group A versus 17\% in group B) (Table 4). The percentage of failure of passive transfer in calves, based on serum TP was $46 \%$ and $48 \%$, for treatments $A$ and $B$, respectively. No significant difference $(p>0.1)$ between the treatments was seen in the total proteins $(p=0.56)$, thyroxin $(p=0.50)$ and tri-iodothyronine $(\mathrm{p}=0.27)$ in the calves' blood 48 hours after birth (Table 4).

\section{DISCUSSION AND CONCLUSIONS}

This study was performed under double-blinded conditions to prevent bias in the measurements, either by the farmer or veterinarians involved in the study. At \#0, efforts were made to establish homogeneous subgroups in each farm, especially according to the age, parity and weight of the animals. In Table 3, the balance between the treatments is clearly demonstrated, as shown by the absence of significant differences in the blood parameters. Moreover, the parity structure (primiparous $38 \%$ and pluriparous $62 \%$ ) between the treatments was perfectly balanced (Table 2).

The supplementation of dams went on for at least two months before parturition to adequately influence the mineral status of the dams. A previous study on BB cattle and trace mineral supplementation indicated that a steady-state regarding blood trace minerals

Table 4. Mean (and standard error of the mean (SEM)) blood parameter concentration in calves and colostrum characteristics of the two studied groups.

\begin{tabular}{lccc}
\hline $\begin{array}{l}\text { Blood calves (at 48h) } \\
\text { (adequate status) }\end{array}$ & Group A & Group B & SEM \\
\hline STP $(>56)^{1}(\mathrm{~g} / \mathrm{L})$ & 56.7 & 57.3 & 1.3 \\
T4 adequate $(\mathrm{nmol} / \mathrm{L})$ & 118.2 & 122.5 & 6.0 \\
T3 adequate $(\mathrm{nmol} / \mathrm{L})$ & 1.87 & 2.03 & 0.16 \\
Ratio T4/T3 & 0.016 & 0.018 & 0.001 \\
\hline Colostrum & Group A & Group B & SEM \\
(adequate status) & 176.2 & 173.5 & 7.5 \\
\hline Total Protein $(>140)^{1}(\mathrm{~g} / \mathrm{L})$ & 96.5 & 96.4 & \\
IgG $(>50)^{1}(\mathrm{~g} / \mathrm{L})$ & $276.0 \mathrm{a}$ & $141.8 \mathrm{~b}$ & 16.0 \\
$\mathrm{Se}(>180)^{2}(\mu \mathrm{g} / \mathrm{kg})$ & & & \\
\hline
\end{tabular}

a,b: $(\mathrm{p}<0.05)$

STP: serum total protein

T4: thyroxin

T3: tri-iodo-thyronine

${ }^{1}$ :Vandeputte et al., 2011; ${ }^{2}$ :Guyot et al., 2007 
is reached after two months (Guyot et al., 2007). The trace mineral status does not change thereafter, even when the supplementation is still occurring at an optimal dosage.

This study took place in properly managed farms, as proven by the relatively correct zootechnical results and below average morbidity $(<20 \%)$ and mortality $(<9 \%)$ rates for calves (adapted from Radostits, 2001). Moreover, the trace mineral status at \#0 was globally adequate for $\mathrm{Zn}$ and $\mathrm{Cu}$ but marginal to deficient for Se and I in most farms. Strictly, when a study aims to demonstrate a significant effect of organic $\mathrm{Zn}$, $\mathrm{Cu}$ or Se supplementation by means of different mineral availability, it should be carried out in mineral deficient animals, also occurring in properly managed farms. Health and performance effects of trace mineral supplementation are only marked if cattle are deficient, especially for Se (Guyot et al., 2007; Corah and Ives, 1991; Wichtel et al., 1996). This study was not designed as a mineral deficiency model. Working with mineral deficiency animals would lead to the risk that the observed effects might be only due to the trace mineral supplementation, whatever the form (organic versus inorganic). The present trial tested the potential advantage of partially supplementing cattle with organic mineral forms rather than testing the effects of a supplementation regimen on the health and performance parameters. This probably explains why the authors observed no significant effects on the health and performance of either dams or calves as the mineral requirements of the dams were fully met. In the present trial, the colostrum quality (IgG concentration) was not affected by the form of minerals, for this same reason. This observation was in accordance with previous findings on Holstein cows (Karkoodi et al., 2012). Awadeh et al. (1998) have demonstrated that Se supplementation of deficient beef cows may improve the IgG concentration in the colostrum. However, this effect is mainly related to the concentration of the Se provided rather than the form of the Se. Finally, regarding the trace mineral status, as the $\mathrm{Cu}$ status was globally adequate in all farms at $\# 0$, it was not surprising to observe an adequate status at \#4 in both groups and in all farms after supplementation, regardless of the mineral source used. Regarding Zn, the same observations were made, even though the status at \#0 involved more farms with marginal statuses. At \#4, the $\mathrm{Zn}$ status was better in both groups in all farms, but a trend $(\mathrm{p}=0.08)$ was detected in favor of group $\mathrm{A}$ regarding the number of animals with an adequate status $(82 \%$ of the animals with adequate status in group A versus $61 \%$ in group B). These $\mathrm{Zn}$ and $\mathrm{Cu}$ statuses are further discussed in relation with the overall health and inflammation status of the animals. To obtain objective, comparable and interpretable data, morbidity and mortality were also analyzed in the sucking group of calves. Actually, this group contained the majority of tested calves in the study. Moreover, milk-replacer fed calves were more heterogeneous, as the quantity of feed and quality of milk-replacers varied widely between farms. Suckling calves may also receive a continuous trace mineral supplementation through the milk of their dams; however, a higher trace element content of the milk was not clearly demonstrated, except for Se.

After approximately two months of supplementation, the dams reached a steady-state in terms of their blood $\mathrm{Zn}$ and $\mathrm{Cu}$ statuses, which decreased and reached the basal concentration at the end of the study (\#5=\#0). Nevertheless, a decreased concentration of Se was observed in both groups at \#4. During the third trimester of pregnancy, Se is transferred from dam to calf via the placenta (Van Saun et al., 1989). By contrast, for $\mathrm{Zn}$ and $\mathrm{Cu}$, placental transfer occurs in the beginning of gestation (Hidiroglou, 1980; Hidiroglou and Knipfel, 1981). This process reduces the blood Se pool in the dam, which will progressively re-increase during the first month post partum (Miller et al., 1995). However, the \#4 Se concentration in the dams is higher than that of \#0 but not higher than \#1. As expected, the Se concentration in the blood was already higher in the treatment A group at \#1 and remained higher throughout the trial. In another study on Se supplementation in BB, a significant difference in favor of the organic form of Se, compared to the inorganic form, was also observed two months after the beginning of supplementation (Guyot et al., 2007). Furthermore, as demonstrated in the present study, the Se content of colostrum was also proven to be higher when using the organic form of Se (Juniper et al., 2006; Guyot et al., 2007). In the present study, the organic forms of $\mathrm{Zn}$ and $\mathrm{Cu}$ did not seem to present a significant advantage. On the one hand, the bioavailability of $\mathrm{Zn}$ and $\mathrm{Cu}$, even under organic forms, may not be as effective as selenomethionine, which is incorporated in an amino-acid. On the other hand, the $\mathrm{Zn}$ and $\mathrm{Cu}$ statuses were not deficient at $\# 0$. This situation might have a negative impact on the ability to demonstrate the potential superiority of organic forms of $\mathrm{Zn}$ and $\mathrm{Cu}$. The condition was different for Se, which was already considered to be deficient at \#0.

A sustained effect of the greater efficacy of organic Se supplementation was perceived until the end of the trial, although supplementation ceased at calving. The higher plasmatic Se concentration in treatment A was indicative of protein enrichment in Se due to the unspecific incorporation of selenomethionine into proteins instead of methionine. This represents a reservoir of Se for animals. Iodine was added to the mineral mix of the study to avoid imbalances between trace minerals. For example, Se supplementation may influence the I status reciprocally (Guyot et al., 2011a). Because plasmatic inorganic iodine is a fast and early marker compared to the others studied here (plasma $\mathrm{Se}, \mathrm{Zn}$ and $\mathrm{Cu}$ ), as it varies measurably after only a few days of supplementation (Rogers, 1999), this element was chosen as a random internal control for supplementation but was not in- 
cluded in the results. PII was only measured at $\# 0$, as a reference for the random internal control of previous supplementation. There was no indication to compare PII at the end of the study, as the authors had already performed thyroid hormone assays and because the same inorganic form of I was used in both groups. Nonetheless, there was no observed effect of the supplementation on the T3-T4 blood concentrations (and their ratio) in both groups, although Se and I are both involved in thyroid hormones synthesis. Data from the literature are controversial regarding the effects of providing organic Se supplementation (Wichtel et al., 1996; Awadeh et al., 1998) or not (Gunter et al., 2013 ) in dams and their calves regarding thyroid hormones. However, the results of the study of Awadeh et al. (1998) were mainly influenced by differences in the amounts of Se fed rather than the sources of Se. Similarly, Guyot et al. (2011a) observed that an extra-supplementation of inorganic Se and I in Holstein cows during four months, compared to animals fed lower amounts, seemed to affect the thyroid hormone concentrations. Their study showed a decreased thyroxin and thyroid hormone ratio and an increased tri-iodothyronine concentration. This may be due to a higher transformation rate of thyroxin to tri-iodo-thyronine by the Se-dependent enzyme de-iodinase type I in peripheral tissues (Wichtel et al., 1996; Awadeh et al., 1998). In the current study, in contrast to these previous deficient-model trials in the literature, the Se and I requirements were almost met, at least marginal in either group at \#4, explaining the absence of differences between the groups.

Treatment A dams at \#4 were characterized by an equivalent $\mathrm{Cu}$ status and trend towards a better $\mathrm{Zn}$ status, compared to treatment $\mathrm{B}$. The effects of the form of $\mathrm{Zn}$ and $\mathrm{Cu}$ supplementation are the subject of several studies, which have conflicting results. Some authors have reported no effect of the source of $\mathrm{Zn}$ or $\mathrm{Cu}$ on their blood status, immune response, reproductive performance, lameness score or colostrum/milk production (Karkoodi et al., 2012; Wang et al., 2013), whereas other authors observed an enhanced immune response of early lactation dairy cows fed chelated sources of $\mathrm{Zn}$ and $\mathrm{Cu}$ compared to cows supplemented with the same amount of inorganic sources (Nemec et al., 2012). In the present study, no significant difference between treatment groups could be demonstrated.

Selenium also plays a role in the immune and inflammatory responses in periparturient cattle (Sordillo, 2013). In this study, haptoglobin was punctually used after calving to provide information on the inflammatory process following cesarean section. Haptoglobin is an acute phase protein that is commonly used in cattle to measure inflammation. This marker has a half-life of approximately four days. Its concentration remains elevated (up to $150 \mathrm{mg} / \mathrm{L}$ ) during the first 8-10 days post partum, but stays low without inflammation in other circumstances (e.g. \#0) (Humblet et al., 2006). Blood samples collected two weeks post partum (\#4) should reveal an absence of inflammation $(\mathrm{Hp}<150 \mathrm{mg} / \mathrm{L})$ in dams; however, dams from treatment group B presented significantly higher haptoglobin concentrations that were above the threshold than dams from treatment group A. The study of Humblet et al. (2006) was performed on the Holstein breed, with natural calving, unlike the present study, where all calvings took place by cesarean section, as occurs in the majority of cases in the Belgian Blue breed. This surgery may potentially extend the inflammatory status after calving due to the time for recovery and cicatrization and may also lead to complications (Kolkman et al., 2007). Nevertheless, the better trace mineral status $(\mathrm{Se})$ of the dams at that period in treatment group A could explain the lower levels of observed inflammation and hence the lower haptoglobin levels seen after calving. Se and $\mathrm{Zn}$ have roles in immunity and wound cicatrization (Graham, 1991). As the treatment B animals apparently had more inflammation, as evidenced by their higher haptoglobin concentration, there could be a concomitant artefactual increase of the $\mathrm{Cu}$ concentration and decrease in the $\mathrm{Zn}$ concentration, erasing the potential differences in the $\mathrm{Zn}$ and $\mathrm{Cu}$ statuses between groups at \#4. Indeed, inflammation may lead to artificially decreased $\mathrm{Zn}$ and increased $\mathrm{Cu}$ concentrations (Milanino et al., 1986; Oliva et al., 1987). Ceruloplasmin, a Cu-containing inflammatory protein, may play a major role in that process. Ceruloplasmin measurements may have been helpful when assessing the influence of inflammation on the $\mathrm{Zn}$ and $\mathrm{Cu}$ statuses in treatment group B at \#4. This hypothesis concerning inflammation should be further investigated. Unfortunately, after the trial, the cattle herds were turned out to pasture, and further reproductive performances were therefore not registered. In a recent study on dairy cows, Nightingale et al. (2015) reported that a strong acute phase response in the early postpartum period, as measured by the Hp concentration, led to an impaired reproductive performance, with an increased duration of the calving-toconception interval.

Further studies could approach the sustained effect of dam's supplementation on the calf trace minerals status as well as the dams health and reproductive performance.

\section{CONCLUSIONS}

Supplying half of the necessary $\mathrm{Se}, \mathrm{Zn}$ and $\mathrm{Cu}$ in organic forms in well-managed and marginally mineral deficient BB farms led to a better Se status in dams and a greater Se supply to their progeny through the colostrum. This effect persisted two months after the discontinuation of the supply of organic Se (\#5). A trend towards a better herd Zn status was also found two weeks after calving in association with organic mineral supplementation. The occurrence of a high haptoglobin concentration (above threshold) was significantly and more frequently encountered two weeks 
after calving (by cesarean section) while feeding the dams with $100 \%$ inorganic forms of trace elements. A partial formulation of the mineral supplement with organic trace minerals $(50 \%$ organic $+50 \%$ inorganic) resulted in a greater nutritional efficacy to sustain the Se status and to lower the haptoglobin concentration after cesarean section, suggesting a decrease in inflammation. Such a decrease in inflammation might result in fewer complications in transition Belgian Blue cows.

\section{ACKNOWLEDGEMENTS}

The authors thank P. Peeters, A. Balthazard, D. Cherdon, P. Monin, T. Detobel, S. Samyn, J. Desmet, J. Degrande, M. Bihain, J. Weinquin, J. Degavre and G. Devaux for their great help in sampling the dams and calves after the cesarean section. J. Detilleux (ULg) must also be acknowledged for the complete review of the study design and statistical interpretation. Finally, the authors warmly thank the farmers involved in the present trial for their help, their herd, and their patience.

\section{REFERENCES}

Abdelrahman M.M., Kincaid R.L. (1993). Deposition of copper, manganese, zinc, and selenium in bovine fetal tissue at different stages of gestation. Journal of Dairy Science 76, 3588-3593.

Abdelrahman M.M., Kincaid R.L. (1995). Effect of selenium supplementation of cows on maternal transfer of selenium to fetal and newborn calves. Journal of Dairy Science 78, 625-630.

Aumont G., Tressol J-C. (1987). Rapid method for the direct determination of inorganic iodine in plasma using ion-exchange chromatography and the Sandell and Kolthoff reaction. Analyst 112, 875-878.

Awadeh F.T., Kincaid R.L., Johnson K.A. (1998). Effect of level and source of dietary selenium on concentrations of thyroid hormones and immunoglobulins in beef cows and calves. Journal of Animal Science 76, 1204-1215.

Corah L.R., Ives S. (1991). The effects of essential trace minerals on reproduction in beef cattle. Veterinary Clinics of North America: Food Animal Practice 7, 41-57.

Enjalbert F., Lebreton P., Salat O. (2006). Effects of copper, zinc and selenium status on performance and health in commercial dairy and beef herds: retrospective study. Journal of Animal Physiology and Animal Nutrition 90, 459-466.

Ferrel C.L., Jenkins T.G. (1998). Body composition and energy utilization by steers of diverse genotypes fed a highconcentrate diet during the finishing period: I. Angus, Belgian Blue, Hereford, and Piedmontese sires. Journal of Animal Science 76, 637-646.

Graham T.W. (1991). Trace elements deficiencies in cattle. Veterinary Clinics of North America: Food Animal Practice 7, 153-215.

Gunter S.A., Beck P.A., Hallford D.M. (2013). Effects of supplementary selenium source on the blood parameters in beef cows and their nursing calves. Biological Trace Element Research 152, 204-211.

Guyot H., Rollin F. (2007). Le diagnostic des carences en Iode et Sélénium chez les bovins. Annales de Médecine Vétérinaire 151,166-191.

Guyot H., Spring P., Andrieu S., Rollin F. (2007). Comparative responses to sodium selenite and organic selenium supplements in Belgian Blue cows and calves. Livestock Science 111, 259-263.

Guyot H., Saegerman C., Lebreton P., Sandersen C., Rollin F. (2009). Epidemiology of trace elements deficiencies in Belgian beef and dairy cattle herds. Journal of Trace Elements in Medicine and Biology 23, 116-123.

Guyot H., Alves de Oliveira L., Ramery E., Beckers J-F., Rollin F. (2011a) Effect of a combined iodine and selenium supplementation on I and Se status of cows and their calves. Journal of Trace Elements in Medicine and Biology 25, 118-124.

Guyot H., Lamain G., Detilleux J., Ramery E. (2011b). Accuracy of inflammation field tests in cattle practice. In: Proceeding of the $6^{\text {th }}$ European Congress of Bovine Health Management. Liège, Belgium.

Herdt H.T., Rumbeiha W., Braselton W.E. (2000). The use of blood analyses to evaluate mineral status in livestock. Veterinary Clinics of North America: Food Animal Practice 16, 423-444.

Hidiroglou M. (1980). Trace elements in the fetal and neonate ruminant: a review. Canadian Veterinary Journal $21,328-335$.

Hidiroglou M., Knipfel J.E. (1981). Maternal-fetal relationships of copper, manganese, and sulphur in ruminants: a review. Journal of Dairy Science 64, 1637-1647.

Humblet M.F., Guyot H., Boudry B., Mbayahi F., Hanzen C., Rollin F., Godeau J.M. (2006). Relationship between haptoglobin, serum amyloid A, and clinical status in a survey of dairy herds during a 6-month period. Veterinary Clinical Pathology 35, 188-193.

Institut National de la Recherche Agronomique (INRA) (1988). R. Jarrige (editor). Alimentation des Bovins, Ovins et Caprins. INRA Publications, Paris.

Juniper D.T., Phipps R.H., Jones A.K., Bertin G. (2006). Selenium supplementation of lactating dairy cows: effect on selenium concentration in blood, milk, urine, and feces. Journal of Dairy Science 89, 3544-3551.

Karkoodi K., Chamani M., Beheshti M., Mirghaffari S.S., Azarfar A. (2012). Effect of zinc, manganese, copper, and selenium chelates on colostrum production and reproduction and lameness indices in adequately supplemented Holstein cows. Biological Trace Element Research 146, 42-46.

Kolkman I., De Vliegher S., Hoflack G., Van Aert M., Laureyns J., Lips D., de Kruif A., Opsomer G. (2007). Protocol of the caesarean section as performed in daily bovine practice in Belgium. Reproduction in Domestic Animals 42, 583-589.

Malcolm-Callis K.J., Duff G.C., Gunter S.A., Kegley E.B., Vermeire D.A. (2000). Effects of supplemental zinc concentration and source on performance, carcass characteristics, and serum values in finishing beef steers. Journal of Animal Science 78, 2801-2808.

Mee J.F., Rogers P.A.M. (1994). Base-line survey of blood trace element status of 50 dairy herds in the south of Ireland in the spring and autumn of 1991. Irish Veterinary Journal 47, 115-122. 
Milanino R., Cassini A., Conforti A., Franco L., Marrella M., Moretti V., Velo G.P. (1986). Copper and zinc status during acute inflammation: studies on blood, liver and kidneys metal levels in normal and inflamed rats. Agents Action 19, 215-223.

Miller G.Y., Bartlett P.C., Erskine R.J., Smith K.L. (1995). Factors affecting serum selenium and vitamin $\mathrm{E}$ concentrations in dairy cows. Journal of the American Veterinary Medical Association 206, 1369-1373.

Muniz-Naveiro O., Dominguez-Gonzalez R., BermejoBarrera A., Cocho de Juan J.A., Fraga Bermudez J.M., Goris Pereiras A., Lopez Santamarina A., Martinez Lede I., Valledor Puente J., Fernandez-Couto Gomez L., Bermejo-Barrera P. (2008). Selenium content and distribution in cow's milk supplemented with two dietary selenium sources. Journal of Agricultural Food Chemistry 53, 9817-9822.

Nemec L.M., Richards J.D., Atwell C.A., Diaz D.E., Zanton G.I., Gressley T.F. (2012). Immune responses in lactating Holstein cows supplemented with $\mathrm{Cu}, \mathrm{Mn}$, and $\mathrm{Zn}$ as sulfates or methionine hydroxyl analogue chelates. Journal of Dairy Science 95, 4568-4577.

Nightingale C.R., Sellers M.D., Ballou M.A. (2015). Elevated plasma haptoglobin concentrations following parturition are associated with elevated leukocyte responses and decreased subsequent reproductive efficiency in multiparous Holstein dairy cows. Veterinary Immunology and Immunopathology 164, 16-23.

National Research Council (2000). Nutrient Requirements of Beef Cattle. $7^{\text {th }}$ Revised edition, National Academy Press: Washington.

Nockels C.F., DeBonis J., Torrent J. (1993). Stress induction affects copper and zinc balance in calves fed organic and inorganic copper and zinc sources. Journal of Animal Science 71, 2539-2545.

Oliva J.C., Castell M., Querazt J., Castellote C. (1987). Effect of chronic inflammation on copper and zinc metabolism. Revista Espanola de Fisiologia 46, 25-31.
Owen J.A., Better F.C., Hoban J. (1960). A simple method for the determination of serum haptoglobins. Journal of Clinical Pathology 13, 163-164.

Radostits O.M. (2001). Food animal production medicine. In: Otto M. Radostits (editor), Herd Health. $3^{\text {rd }}$ Edition, W.B. Saunders Company, Philadelphia, USA, pp. 884.

Rogers P.A.M. (1999). Iodine supplementation of cattle. Beef Production Series 20, 3-34.

Rosenberger G. (1990). Die klinische Untersuchung des Rindes. $3^{\text {rd }}$ Edition, Berlin, Germany: Verlag Paul Parey.

Schlegel P., Hansen S.L., Lloyd K.E., Legleiter L.R., Spears J.W. (2006). Bioavailability of copper glycinate in steers when fed increasing amounts of copper antagonists. Rencontres Recherche Ruminants 13.

Sordillo L.M. (2013). Selenium-dependent regulation of oxidative stress and immunity in periparturient dairy cattle. Veterinary Medicine International 2013, 154045.

Vandeputte S., Detilleux J., Rollin F. (2011). Comparison of four refractometers for the investigation of passive transfer in beef calves. Journal of Veterinary Internal Medicine 25, 1465-1469.

Van Saun R.J., Herdt T.H., Stowe H.D. (1989). Maternal and fetal selenium concentrations and their interrelationships in dairy cattle. Journal of Nutrition 119, 1128-1137.

Wang R.L., Liang J.G., Lu L., Zhang L.Y., Li S.F., Luo X.G. (2013). Effect of zinc source on performance, zinc status, immune response, and rumen fermentation of lactating cows. Biological Trace Elements Research 152, 16-24.

Wichtel J.J., Craigie A.L., Freeman D.A., Varela-Alvarez H., Williamson N.B. (1996). Effect of selenium and iodine supplementation on growth rate and on thyroid and somatotropic function in dairy calves at pasture. Journal of Dairy Science 79, 1865-1872. 